Ekspansi: Jurnal Ekonomi, Keuangan, Perbankan dan Akuntansi

ISSN (Online): 2580-7668 ISSN (Print): 2085-5230

Vol. 12, No. 2 (November 2020), Hal. 307 - 324

\title{
KINERJA BANK PEMBIAYAAN RAKYAT SYARIAH BERDASARKAN SHARIA MAQASHID INDEX (Studi pada BPRS di Provinsi Jawa Barat Tahun 2016-2018)
}

\author{
Aneu Cakhyaneu ${ }^{1}$, Fani Puspitasari ${ }^{2}$, Heraeni Tanuatmodjo ${ }^{3}$, Firmansyah $^{4}$ \\ 1,2,3,4 Ilmu Ekonomi dan keuangan Islam, Universitas Pendidikan Indonesia, Bandung, \\ Indonesia \\ Email Korespondensi: aneufpeb@upi.edu
}

\begin{abstract}
This sharia banking requires a measurement of performance as sees from the aspect of sharia or maqashid shariah which aims to realize the goal of sharia is achieve the welfare of the ummah. This study aims to analyze the performance of Sharia Rural Bank based on Sharia Maqashid Index (SMI) by using the Simple Additive Weighthing Method (SAW). The method used in this research is quantitative descriptive method with the object to be studied, that is eleven Sharia Rural Bank (BPRS) in West Java Province. The results of this study state that the best performance based on the Sharia Maqashid Index (SMI) is BPRS Artha Karimah Irsyadi Bekasi City. This is because BPRS Artha Karimah Irsyadi Bekasi City has been supported by the highest score in the first performance indicator (Tahdzib Al fard). This research is expected to be taken into consideration for the related institutions to apply the performance measurement of sharia banks in accordance with the concept of maqashid shariah and be taken into consideration in taking policy measures in accordance with the concept of sharia which will be used in the future.
\end{abstract}

Keywords: Sharia Maqashid Index, Tahdzib Al-Fard, Iqamah Al-Adl, Jalb Al-Maslahah.

Abstrak: Perbankan syariah memerlukan sebuah pengukuran kinerja yang melihat dari aspek syariah atau maqashid syariah yang bertujuan untuk mewujudkan tujuan syariah yaitu menciptakan kesejahteraan ummat. Penelitian ini bertujuan untuk menganalisis kinerja Bank Pembiayaan Rakyat Syariah berdasarkan Sharia Maqashid Index (SMI) dengan menggunakan metode Simple Additive Weighthing Method (SAW). Metode yang digunakan dalam penelitian ini yaitu metode deskriptif kuantitatif dengan dengan objek yang akan diteliti yaitu sebelas Bank Pembiayaan Rakyat Syariah (BPRS) di Provinsi Jawa barat. Hasil dari penelitian ini menyatakan bahwa yang memiliki kinerja terbaik berdasarkan Sharia Maqashid Index (SMI) yaitu BPRS Artha Karimah Irsyadi Kota Bekasi. Hal ini dikarenakan BPRS Artha Karimah Irsyadi Kota Bekasi telah didukung oleh perolehan nilai tertinggi dalam pencapaian indikator kinerja tujuan pertama (Tahdzib Al fard). Penelitian ini diharapkan dapat dijadikan bahan pertimbangan bagi instansi terkait untuk menerapkan pengukuran kinerja Bank Pembiayaan Rakyat Syariah yang sesuai dengan konsep maqashid syariah serta dijadikan bahan pertimbangan dalam mengambil langkah-langkah kebijakan yang sesuai dengan konsep syariah yang akan di gunakan kedepannya.

Kata Kunci: Sharia Maqashid Index, Tahdzib Al-Fard, Iqamah Al-Adl, Jalb Al-Maslahah.

DOI: $10.35313 /$ ekspansi.v12i2.2210 


\section{PENDAHULUAN}

Pengukuran kinerja perbankan tidak cukup dengan hanya menggunakan rasio keuangan karena bank syariah sebagai salah satu entitas bisnis syariah berbeda dengan bank konvensional sehingga tidak hanya dituntut untuk mengukur kinerja secara finansial saja tetapi juga harus diukur dari segi ketercapaian tujuan syariah yaitu maqashid syariah sehingga dapat diketahui apakah kinerja perbankan tersebut telah sesuai dengan nilai dan prinsip syariah atau tidak (Afrinaldi, 2013). Untuk mengevaluasi pencapaian maqasid syariah di perbankan syariah, Mustafa Umar Mohammed sebagai mana yang dikutip oleh Rosanti (2019) telah mengembangkan suatu metode yang disebut sharia maqasid index.

Mohammed mengusulkan tujuan perbankan syariah berdasarkan perspektif maqasid syariah. Melalui metode tersebut, tujuan perbankan syariah dijabarkan menjadi indikator kinerja yang terukur (Rosanti, 2019). Metode tersebut sebagai alat ukur kinerja perbankan syariah dalam mengidentifikasi unsur ke-Islamannya. Unsur tersebut berupa porsi produk yang berbasis bagi hasil, porsi zakat, dan rasio lainnya seperti yang terdapat dalam komposisi Sharia Maqashid Index (SMI) (Batin, 2017). Menurut Antonio dkk (2012) dalam SMI terdapat tiga konsep untuk mengukur kinerja yaitu, mendidik individu (Tahdzib al-Fard), menegakkan keadilan (Iqamah al-'Adl) dan mencapai kesejahteraan (Jalb al-Maslahah). Masing-masing dari konsep tersebut memiliki beberapa elemen dan rasio yang dapat diukur.

BPRS yang menjadi objek dalam penelitian ini adalah BPRS yang beroperasi di Provinsi Jawa Barat, penelitian ini juga dilakukan untuk mengetahui bagaimana kinerja BPRS yang berada di Provinsi Jawa Barat, karena sejauh ini belum ada penelitian yang meniliti objek yang sama dengan penelitian yang akan teliti saat ini. Selain itu juga untuk mengetahui apakah kinerja BPRS di Provinsi Jawa Barat telah sesuai dengan nilai dan prinsip syariah atau tidak, dan juga untuk membandingkan BPRS manakah di Provinsi Jawa Barat yang memiliki nilai Sharia Maqashid terbaik.

Salah satu elemen yang termasuk ke dalam konsep menegakkan keadilan (Iqamah al-'Adl) ialah dengan melakukan pembiayaan berbasis bagi hasil seperti mudharabah dan musyarakah sebagaimana diketahui bahwa pembiayaan bagi hasil ini merupakan ciri utama dari operasional bank syariah dibandingkan dengan jenis pembiayaan lainya.

Berikut adalah rata-rata perbandingan pembiayaan bagi hasil dan pembiayaan lainnya pada BPRS di Provinsi Jawa Barat selama tiga tahun terakhir yaitu 2016-108:

\section{Tabel 1}

Rata-rata Pembiayaan Musyarakah dan Murabahah pada BPRS di Provinsi Jawa Barat Tahun 2016-2018

\begin{tabular}{|c|c|c|}
\hline Tahun & Musyarakah & Murabahah \\
\hline 2016 & 1.977 .489 & 37.041 .414 \\
\hline 2017 & 2.906 .649 & 39.129 .712 \\
\hline 2018 & 3.819 .718 & 40.276 .940 \\
\hline
\end{tabular}


Berdasarkan data di atas, dapat dilihat bahwa rata-rata pembiayaan musyarakah atau pembiayaan bagi hasil lebih sedikit dibandingkan dengan pembiayaan murabahah atau pembiayaan lain bukan bagi hasil, walaupun dari tahun ke tahunnya mengalami kenaikan. Namun, dengan kecilnya porsi pembiayaan bagi hasil ini menunjukkan bahwa salah satu indikator dari ketercapaian Maqashid Syariah kurang maksimal. Seperti yang telah dijelaskan sebelumnya bahwa pembiayaan berbasis bagi hasil seperti pembiayaan musyarakah merupakan ciri utama dari operasional bank syariah dibandingkan dengan jenis pembiayaan lainya, sehingga dengan kata lain kecilnya porsi pembiayaan bagi hasil pada BPRS di Provinsi Jawa Barat ini menunjukkan kurang optimalnya Iqamah al-Adl atau penegakkan keadilan untuk ketercapaian Maqashid Syariah. Padahal sebagai salah satu entitas bisnis syariah, pembiayaan berbasis bagi hasil telah sepatutnya dilakukan oleh Bank Pembiayaan Rakyat Syariah, selain untuk memenuhi kebutuhan perusahaan juga untuk membantu pengembangan ekonomi umat.

Berdasarkan latar belakang permasalah di atas, perlu kiranya dilakukan sebuah penelitian terkait MSI untuk mengukur apakah BPRS di Provinsi Jawa Barat telah sesuai dengan syariah atau tidak ditinjau dari ketiga konsep yang ada dalam Sharia Maqashid Index yaitu mendidik individu (Tahdzib al-Fard), menegakkan keadilan (Iqamah al-Adl) dan mencapai kesejahteraan (Jalb al-Maslahah), sehingga dalam hal ini penulis tertarik untuk melakukan penelitian dengan judul "Kinerja Bank Pembiayaan Rakyat Syariah Berdasarkan Sharia Maqashid Index (Studi Pada BPRS Di Provinsi Jawa Barat Tahun 2016-2018)”.

\section{TINJAUAN PUSTAKA}

\subsection{Teori Kinerja}

Menurut Mahsun (2011) kinerja adalah gambaran mengenai tingkat pencapaian pelaksanaan suatu kegiatan/program dalam mewujudkan sasaran, tujuan, misi dan visi organisasi yang terdapat dalam strategic planing suatu organisasi. Istilah kinerja sering digunakan untuk menyebut prestasi atau tingkat keberhasilan individu maupun kelompok. Kinerja bisa diketahui hanya jika individu atau kelompok tersebut mempunyai kriteria keberhasilan yang telah ditetapkan sebelumnya (Safwan, Nadirsyah, \& Abdullah, 2014). Menurut Jaya dkk (2012) kinerja merupakan fungsi interaksi antara kemampuan atau Ability (A), motivasi atau Motivation (M) dan kesempatan atau Opportunity.

\subsection{Konsep Kinerja dalam Perspektif Islam}

Berdasarkan cara pandang agama Islam tergambar bahwa orientasi kinerja tidak hanya untuk memaksimalkan laba semata seperti penggunaan pada metode penilaian kinerja konvensional, tetapi orientasi kinerja perlu meliputi dimensi yang lebih luas dan menyeluruh, yakni kesejahteraan para stakeholder meliputi investor, karyawan, pelanggan, pemasok, komunitas, lingkungan/sosial dan generasi yang akan datang (Ramadhan \& Ryandono, 2015).

Sebagaimana Allah swt., berfirman dalam Q.S at-Taubah ayat 105: 


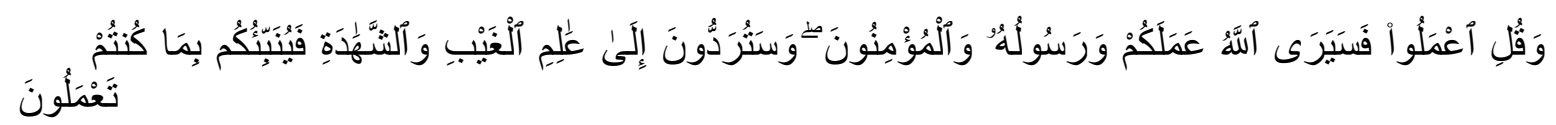

Dan Katakanlah: "Bekerjalah kamu, maka Allah dan Rasul-Nya serta orang-orang mukmin akan melihat pekerjaanmu itu, dan kamu akan dikembalikan kepada (Allah) Yang Mengetahui akan yang ghaib dan yang nyata, lalu diberitakan-Nya kepada kamu apa yang telah kamu kerjakan”. (Q.S. at-Taubah [9]: 105).

\subsection{Konsep Maqashid Al-Syari'ah}

Asafri Jaya, sebagaimana dikutip oleh Shidiq (2009) Maqashid al-syari'ah terdiri dari dua kata, maqashid dan syari'ah. Kata maqashid merupakan bentuk jama' dari maqshad yang berarti maksud dan tujuan, sedangkan syari'ah mempunyai pengertian hukum-hukum Allah yang ditetapkan untuk manusiaagar dipedomani untuk mencapai kebahagiaan hidup di dunia maupun di akhirat. Maka dengan demikian, maqashid alsyari'ah berarti kandungan nilai yang menjadi tujuan pensyariatan hukum. Maka dengan demikian, maqashid al-syari'ah adalah tujuan-tujuan yang hendak dicapai dari suatu penetapan hukum.

Sedangkan secara terminologi, menurut Hasan (2017) pengertian maqashid alsyari'ah yang dikemukakan oleh beberapa ahli antara lain:

\section{a. Al-Ghazali}

Penjagaan terhadap maksud dan tujuan syariah adalah upaya mendasar untuk bertahan hidup, menahan faktor-faktor kerusakan, dan mendorong terjadinya kesejahteraan.

\section{b. Al-Syatibi}

Maqashid terbagi menjadi dua: yang pertama, berkaitan dengan maksud Tuhan selaku pembuat syariah dan yang ke dua, berkaitan dengan maksud mukallaf.

\section{c. Al-Fasi}

Maqashid al-syari'ah merupakan tujuan pokok syariah dan rahasia dari setiap hukum yang ditetapkan oleh Tuhan.

\section{d. Al-Raysuni}

Maqashid al-syari'ah merupakan tujuan-tujuan yang telah ditetapkan oleh shari'ah untuk dicapai demi kemaslahatan manusia.

\subsection{Pengukuran Maqashid Syariah Index (SMI)}

Mustofa Omar Mohammed dkk (2008) memberikan contoh dalam menggunakan metode Sekaran yaitu dengan menggambarkan perilaku haus yang dialami seseorang. Perilaku haus tersebut adalah konsep (C) dalam metode ini. Perilaku haus dapat diukur dengan menghitung seberapa sering seseorang meminum cairan yang disebut dimensi (D). Dimensi diturunkan lagi ke dalam unsur-unsur yang lebih terukur misalnya mengukur berapa gelas cairan yang telah dihabiskan oleh orang tersebut untuk menghilangkan hausnya. Berapa gelas inilah yang disebut dengan unsur (E) sehingga dapat diukur secara lebih pasti. 
Tabel 2

Model Pengukuran Sharia Maqashid Index (SMI)

\begin{tabular}{|c|c|c|}
\hline & & \\
\hline Tujuan Syariah & Dimensi & Elemen \\
\hline \multirow{3}{*}{$\begin{array}{c}\text { Tahdzib Al Fard } \\
\text { (Mendidik } \\
\text { Individu) }\end{array}$} & D1. Advancement Knowledge & $\begin{array}{l}\text { E1. Education Grand } \\
\text { E2. Reaserch }\end{array}$ \\
\hline & D2. Instilling new skill and improvement & E3. Training \\
\hline & D3. Creating awareness of islamic banking & E4. Publicity \\
\hline \multirow{3}{*}{$\begin{array}{c}\text { Iqamah Al Adl } \\
\text { (Menegakkan } \\
\text { Keadilan) }\end{array}$} & D4. Fair Returns & E5. Fair Returns \\
\hline & D5. Cheap Products and service & $\begin{array}{c}\text { E6. Fungsional } \\
\text { Distribution }\end{array}$ \\
\hline & D6. Elimination of injustices & E7. Interest Free Product \\
\hline \multirow{3}{*}{$\begin{array}{l}\text { Jalb Al Maslahah } \\
\text { (Menciptakan } \\
\text { Kemaslahatan) }\end{array}$} & D7. Profitability of bank & E8. Profit Rations \\
\hline & D8. Redistribution of income \& wealth & E9. Personal Income \\
\hline & D9. Invesment in real sector & $\begin{array}{l}\text { E10. Invesment in real } \\
\text { sector }\end{array}$ \\
\hline
\end{tabular}

Sumber: (Mohammed Eु Razak, 2008)

\section{METODE PENELITIAN}

Penelitian dapat dibedakan sesuai dengan metode yang digunakan dalam menemukan hakekat konsep atau elemen ilmu pengetahuan (Ferdinand, 2014). Metode penelitian atau metode ilmiah adalah prosedur atau langkah-langkah dalam mendapatkan pengetahuan ilmiah atau ilmu. Dengan demikian metode penelitian adalah cara sistematis untuk menyusun ilmu pengetahuan (Suryana, 2010). Metode penelitian yang digunakan dalam penelitian ini menggunakan penelitian kuantitatif dengan pendekatan deskriptif. Menurut Wahidmurni (2017) metode penelitian kuantitatif merupakan suatu cara yang digunakan untuk menjawab masalah penelitian yang berkaitan dengan data berupa angka dan program statistik. Penelitian ini dilakukan dengan mengukur kinerja terhadap BPRS di Provinsi Jawa Barat dengan menerapkan pengukuran kinerja berdasarkan Sharia Maqashid Index (SMI).

Menurut Amirullah (2015) populasi merupakan seluruh kumpulan elemen yang dapat digunakan untuk membuat beberapa kesimpulan. Adapun yang menjadi populasi dalam penelitian ini adalah Bank Pembiayaan Rakyat Syariah (BPRS) yang ada di Provinsi Jawa Barat, yakni berjumlah 29 BPRS. Populasi yang menjadi subjek dalam penelitian ini adalah seluruh BPRS yang beroperasi di Provinsi Jawa Barat yang telah mempublikasikan laporan keuangannya secara lengkap dalam rentang periode 2016-2018.

Sampel adalah subset dari populasi, terdiri dari beberapa anggota populasi. Subset ini diambil karena dalam banyak kasus tidak mungkin kita meneliti seluruh anggota populasi (Ferdinand, 2014). Dalam menentukan sampel diperlukannya sebuah teknik. Adapun teknik sampling yang digunakan yaitu teknik Judgment Sampling atau teknik penentuan sampel dengan menggunakan pertimbangan tertentu yang disesuaikan dengan tujuan penelitian atau masalah penelitian yang dikembangkan (Ferdinand, 2014). Pertimbangannya adalah dengan memilih sampel yakni BPRS yang telah mempublikasikan laporan keuangannya secara lengkap di Otoritas Jasa Keuangan (OJK) periode 2016-2018. 


\section{Tabel 3}

Sampel Penelitian

\begin{tabular}{|c|c|}
\hline No. & Nama Bank \\
\hline 1. & PT BPRS Artha Madani \\
\hline 2. & PT BPRS Amanah Ummah \\
\hline 3. & PT BPRS Artha Fisabilillah \\
\hline 4. & PT BPRS Amanah Rabbaniah \\
\hline 5. & PT BPRS Mentari \\
\hline 6. & PT BPRS Gotong Royong Kabupaten Subang \\
\hline 7. & PT BPRS Baiturridha Pusaka \\
\hline 8. & PT BPRS Al Madinah Tasikmalaya \\
\hline 9. & PT BPRS Daarut Tauhiid \\
\hline 10. & PT BPRS Al Barokah \\
\hline 11. & PT BPRS Artha Karimah Irsyadi \\
\hline
\end{tabular}

\section{HASIL DAN PEMBAHASAN}

4.1 Kinerja Maqashid Syariah pada Bank Pembiayaan Rakyat Syariah di Provinsi Jawa Barat

Dalam mengukur kinerja pada BPRS yang diukur berdasarkan tujuan-tujuan maqashid syariah dapat dilihat melalui rasio kinerja maqashid syariah yang terbagi dalam tiga tujuan yaitu :

1. Tahdzib al-Fard (Mendidik Individu)

2. Iqamah al-Adl (Menegakan Keadilan)

3. Jalb al-Maslahah (Menciptakan Kemaslahatan)

Berikut ini merupakan kinerja maqashid syariah pada 11 BPRS pada periode tahun 2016-2018 pada setiap tujuannya.

\subsection{Nilai Rasio Kinerja Maqashid Syariah}

Tujuan Pertama yaitu Tahdzib al-Fard (Mendidik Individu) yang memiliki empat elemen yang diukur dalam tujuannya yaitu untuk mengetahui seberapa besar kepedulian bank syariah dalam meningkatkan pendidikan dan pengetahuan bagi seluruh stakeholdernya, melakukan penelitian dalam dunia perbankan syariah, memberikan pelatihan kepada pegawai untuk meningkatkan skill dan pengetahuan serta melakukan promosi dan publikasi unutuk meningkatkan pengetahuan masyarakat dalam dunia perbankan syariah. Berikut ini merupakan tabel rasio kinerja maqashid syariah untuk tujuan pertama sebagai berikut : 
Tabel 4

Nilai Rata-Rata Kinerja Maqashid Syariah Tujuan Pertama (Tahdzib Al-Fard) BPRS di Provinsi Jawa Barat Tahun 2016-2018

\begin{tabular}{|c|c|c|}
\hline \multirow{2}{*}{ Bank } & \multicolumn{2}{|c|}{ Rasio Kinerja Tujuan $\mathbf{1}$} \\
\cline { 2 - 3 } & $\mathbf{R}_{1.1}, \mathbf{R}_{3.1}$ & $\mathbf{R}_{\mathbf{2 . 1}}, \mathbf{R}_{4.1}$ \\
\hline BPRS Artha Madani (Kab. Bekasi) & 0,535332359 & 0,231535901 \\
\hline BPRS Amanah Ummah (Kab. Bogor) & 0,592292842 & 0,178534413 \\
\hline BPRS Artha Fisabilillah (Kab. Cianjur) & 0,354273551 & 0,146281948 \\
\hline BPRS Amanah Rabbaniah (Kab. Bandung) & 0,63966289 & 0,23376343 \\
\hline BPRS Mentari (Kab. Garut) & 0,690953468 & 0,250696691 \\
\hline BPRS Gotong Royong (Kab. Subang) & 0,506214548 & 0,18701306 \\
\hline BPRS Baiturridha Pusaka (Kota Bandung) & 0,589128272 & 0,218459877 \\
\hline BPRS Al Madinah (Kota Tasikmalaya) & 0,667817355 & 0,196675596 \\
\hline BPRS Daarut Tauhiid (Kota Cimahi) & 0,476916528 & 0,295524348 \\
\hline BPRS Al Barokah (Kota Depok) & 0,56203227 & 0,266343169 \\
\hline BPRS Artha Karimah Irsyadi (Kota Bekasi) & 0,564933965 & 0,3800632 \\
\hline
\end{tabular}

Sumber: Hasil Pengolahan Data (2020)

Berdasarkan pengolahan data di atas dapat diketahui nilai rasio pertama dan ketiga yaitu hibah pendidikan (education grand) dan pelatihan (training). Adapun yang memperoleh nilai tertinggi pada rasio pertama dan ketiga yaitu BPRS Mentari Kabupaten Garut yang memperoleh nilai sebesar 0,69. Hal ini menunjukan bahwa dari total pengeluarannya sebesar $69 \%$ ditujukan untuk donasi pengembangan pendidikan dan pelatihan. Pelatihan di sini dapat berupa pelatihan yang ditujukan untuk para pegawai guna memperluas pengetahuannya dalam perbankan syariah.

Rasio yang kedua dan keempat yaitu penelitian (research) dan publikasi (publicity), yang memperoleh nilai tertinggi pada rasio kedua dan keempat ini yaitu BPRS Artha Karimah Irsyadi Kota Bekasi yang memperoleh nilai sebesar 0,38 untuk periode 20162018. Hal ini menunjukan 38\% dari total pengelurannya ditujukan untuk kegiatan riset dan pengembangan serta publikasi dan promosi. Riset dan pengembangan ini sangat penting untuk dilakukan bagi kemajuan perbankan dalam menghadapi persaingan. Kegiatan publikasi dan promosi juga sangat penting dilakukan selain untuk mempromosikan produk yang ditawarkan oleh bank, dengan adanya publikasi ini juga mampu meningkatkan pengetahuan masyarakat dalam dunia perbankan syariah. Menurut Triandini (2013) strategi jemput bola dilakukan oleh BPRS Artha Karimah Irsyadi sebagai salah satu strategi promosi yang berupaya mendekatkan diri kepada masyarakat dengan cara mempermudah nasabah untuk mengakses layanan di BPRS Artha Karimah Irsyadi.

Tujuan kedua yaitu Iqamah al-Adl (Menegakan Keadilan). Hal ini dilakukan untuk melihat sejauh mana bank syariah dalam menegakan keadilan sehingga akan tercipta hubungan yang saling menguntungkan. Islam sangat menganjurkan untuk berlaku adil seperti firman Allah swt dalam QS. An-Nahl ayat 90 yang berbunyi:

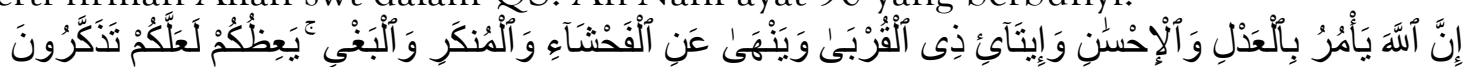

"Sesungguhnya Allah menyuruh (kamu) berlaku adil dan berbuat kebajikan, memberi kepada kaum kerabat, dan Allah melarang dari perbuatan keji, kemungkaran dan permusuhan. 
314 Aneu Cakhyaneu, Fani Puspitasari, Heraeni Tanuatmodjo dan Firmansyah

Dia memberi pengajaran kepadamu agar kamu dapat mengambil pelajaran." (Q.S. An-Nahl [16[:90)

Tujuan kedua ini memiliki tiga elemen yang diukur yaitu pengembalian yang adil (Fair Returns), fungsi distribusi (fungsional distribution) dan produk bank non bunga (interest free product). Berikut ini merupakan tabel rasio kinerja maqashid syariah untuk tujuan kedua yaitu sebagai berikut :

Tabel 5

Nilai Rata-Rata Kinerja Maqashid Syariah Tujuan Kedua (Iqamah Al-AdI) BPRS di Provinsi Jawa Barat Tahun 2016-2018

\begin{tabular}{|l|c|c|c|}
\hline \multirow{2}{*}{ Bank } & \multicolumn{3}{|c|}{ Rasio Kinerja Tujuan 2 } \\
\cline { 2 - 4 } & $\mathbf{R}_{1.2}$ & $\mathbf{R}_{2.2}$ & $\mathbf{R}_{3.2}$ \\
\hline BPRS Artha Madani (Kab. Bekasi) & 0 & 0,109360778 & 0 \\
\hline BPRS Amanah Ummah (Kab. Bogor) & 0 & 0,052102166 & 0 \\
\hline $\begin{array}{l}\text { BPRS Artha Fisabilillah (Kab. } \\
\text { Cianjur) }\end{array}$ & 0 & 0 & 0 \\
\hline $\begin{array}{l}\text { BPRS Amanah Rabbaniah (Kab. } \\
\text { Bandung) }\end{array}$ & 0 & 0,014589978 & 0 \\
\hline BPRS Mentari (Kab. Garut) & 0 & 0,05306365 & 0 \\
\hline BPRS Gotong Royong (Kab. Subang) & 0 & 0,220782358 & 0 \\
\hline $\begin{array}{l}\text { BPRS Baiturridha Pusaka (Kota } \\
\text { Bandung) }\end{array}$ & 0 & 0,011793314 & 0 \\
\hline BPRS Al Madinah (Kota Tasikmalaya) & 0 & 0,037585494 & 0 \\
\hline BPRS Daarut Tauhiid (Kota Cimahi) & 0 & 0,132932055 & 0 \\
\hline BPRS Al Barokah (Kota Depok) & 0 & 0,094790558 & 0 \\
\hline $\begin{array}{l}\text { BPRS Artha Karimah Irsyadi (Kota } \\
\text { Bekasi) }\end{array}$ & 0 & 0,067455446 & 0 \\
\hline
\end{tabular}

Sumber : Hasil Pengolahan Data (2020)

Berdasarkan pengolahan data di atas dapat diketahui rasio pertama yaitu pengembalian yang adil (Fair Returns) yang diukur oleh PER (Profit Equalization Reserve). BPRS di Provinsi Jawa Barat tidak ada yang melaporkan alokasi dana untuk PER pada laporan keuangannya. Hal ini dapat menunjukan bahwa seluruh BPRS di Provinsi Jawa Barat telah berupaya dalam menegakan keadilan. Nurfadhilah (2018) menjelaskan jika bank syariah menetapkan sebagian pendapatannya untuk PER maka ini menunjukan bahwa bank syariah dianggap memungkiri hak deposan dalam memperoleh keuntungannya. Namun, jika angka PER mendekati angka satu bahkan tidak ada cadangan untuk PER maka bank syariah tersebut telah berkomitmen untuk menegakan keadilan.

Rasio yang kedua dari tujuan kedua yaitu fungsi distribusi (fungsional distribution). Nilai fungsi distribusi (fungsional distribution) dapat dilihat dengan menghitung rasio pembiayaan dengan skim bagi hasil yaitu mudharabah dan musyarakah dibandingkan 
dengan pembiayaan dengan skim lain. Pada tabel di atas dapat terlihat yang memiliki nilai rasio tertinggi pada rasio kedua ini yaitu BPRS Gotong Royong Kabupaten. Subang yang memperoleh nilai sebesar 0,22. Hal ini menunjukan bahwa sebesar 22\% pembiayaan yang diberikan oleh BPRS Gotong Royong yaitu dengan menggunakan akad mudharabah dan musyarakah. Namun terdapat satu BPRS yang tidak melaporkan alokasi dana untuk pembiayaan mudharabah dan musyarakah yaitu BPRS Artha Fisabilillah Kabupaten Cianjur.

Rasio yang ketiga dari tujuan kedua yaitu produk bank non bunga (interest free product). Mengukur interest free income dilakukan dengan melihat rasio pendapatan bebas bunga dibandingkan dengan total pendapatan. Pada tabel di atas BPRS di Provinsi Jawa Barat tidak ada yang melaporkan alokasi dana untuk produk bank non bunga pada laporan keuangannya. Hal ini dapat menunjukan bahwa seluruh BPRS di Provinsi Jawa Barat pendapatannya bukan berasal dari hasil riba/bunga.

Tujuan ketiga yaitu Jalb al-Maslahah (Menciptakan Kesejahteraan), pada tujuan ini akan terlihat sejauh mana peran bank syariah untuk menciptakan kesejahteraan umat sebagai tujuan utama dari maqashid syariah. Ada tiga elemen yang diukur pada tujuan ketiga ini yaitu rasio laba (profit ratio), pendapatan personal (personal income) dan investasi sektor riil (invesment ratios in real sector). Berikut ini merupakan nilai rasio untuk tujuan ketiga di setiap BPRS di Provinsi Jawa Barat tahun 2016-2018 yaitu sebagai berikut:

Tabel 6

Nilai Rata-Rata Kinerja Maqashid Syariah Tujuan Ketiga (Jalb al-Maslahah) BPRS di Provinsi Jawa Barat Tahun 2016-2018

\begin{tabular}{|c|c|c|c|}
\hline \multirow{2}{*}{ Bank } & \multicolumn{3}{|c|}{ Rasio Kinerja Tujuan 3 } \\
\cline { 2 - 4 } & $\mathbf{R}_{1.3}$ & $\mathbf{R}_{2.3}$ & $\mathbf{R}_{3.3}$ \\
\hline BPRS Artha Madani (Kab. Bekasi) & 0,005160837 & 0,102692161 & 0 \\
\hline BPRS Amanah Ummah (Kab. Bogor) & 0,016108268 & 0,097875889 & 0 \\
\hline BPRS Artha Fisabilillah (Kab. Cianjur) & $-0,069653902$ & 0 & 0 \\
\hline $\begin{array}{c}\text { BPRS Amanah Rabbaniah (Kab. } \\
\text { Bandung) }\end{array}$ & 0,020022706 & 0,010818238 & 0 \\
\hline BPRS Mentari (Kab. Garut) & 0,014643529 & 0 & 0 \\
\hline BPRS Gotong Royong (Kab. Subang) & $-0,035944169$ & 0 & 0 \\
\hline BPRS Baiturridha Pusaka (Kota & 0,028000283 & 0,022222417 & 0 \\
\hline Bandung) & & 0 & 0 \\
\hline BPRS Al Madinah (Kota Tasikmalaya) & 0,007134481 & 0 & 0 \\
\hline BPRS Daarut Tauhiid (Kota Cimahi) & $-0,007156$ & 0 & 0 \\
\hline BPRS Al Barokah (Kota Depok) & 0,022708046 & 0 & 0 \\
\hline BPRS Artha Karimah Irsyadi (Kota & 0,004355916 & & \\
Bekasi) & & & 0 \\
\hline
\end{tabular}

Sumber : Hasil Pengolahan Data (2020)

Berdasarkan pengolahan data di atas telah terlihat masing-masing nilai di setiap rasio. Rasio yang pertama yaitu rasio laba (profit ratios). Rasio ini menggambarkan kemampuan bank dalam memperoleh laba yang tinggi sebagai sebuah bentuk dari 
hifzul maal (penjagaan terhadap harta) dengan pengelolaan yang optimal dan bijaksana. Pada tabel diatas yang memiliki nilai tertinggi untuk rasio pertama yaitu BPRS Baiturridha Pusaka Kota Bandung yang memiliki nilai sebesar 0,028 atau 2,8\%. Laba yang tinggi dapat memaksimalkan peran BPRS untuk ikut dalam menciptakan kesejahteraan umat, misalnya pembayaran pajak yang digunakan untuk membantu pembangunan negara serta mampu berkontribusi lebih tinggi dalam kemaslahatan masyarakat. Sementara itu BPRS yang memiliki nilai terendah dalam perolehan laba yaitu BPRS Daarut Tauhiid Kota Cimahi yang memiliki nilai rasio sebesar -0,007 atau $-0,7 \%$, atau dapat pula dikatakan bahwa BPRS tersebut mengalami kerugian sebesar 0,7\%. Hal ini dapat terjadi karena BPRS tersebut kurang memaksimalkan dalam pengelolaan aset untuk mendapatkan laba. Selain BPRS Daarut Tauhid, terdapat pula beberapa BPRS yang mengalami kerugian diantaranya adalah BPRS Artha Fisabilillah Kabupaten Cianjur dan BPRS Gotong Royong Kabupaten. Subang.

Rasio yang kedua yaitu pendapatan personal (personal income), untuk mengetahui nilai dari rasio ini dapat tergambar dari rasio zakat yang dikeluarkan oleh BPRS atas aset bersih yang dimiliki oleh bank tersebut. Walaupun pada dasarnya dalam BPRS tidak terdapat fungsi sosial, berbeda dengan Bank Umum Syariah (BUS) yang dapat menjalankan fungsi sosial dalam bentuk lembaga baitul mal, namun terdapat beberapa BPRS yang melaporkan alokasi dana zakat pada laporan keuangannya (Adiyudha \& Amanda, 2019).

Berdasarkan tabel di atas yang memiliki nilai tertinggi dalam rasio kedua yaitu BPRS Artha Madani Kabupaten Bekasi yang memiliki nilai sebesar 0,10 atau 10\% untuk pembayaran zakat dari total aset bersih. Semakin besarnya dana zakat yang dikeluarkan oleh BPRS maka peran BPRS semakin besar dalam mewujudkan kesejahteraan masyarakat yang tersalurkan melalui program-program yang dikelola BPRS Artha Madani Kabupaten Bekasi seperti penyaluran dana melalui pemberdayaam ekonomi umat melalui LAZ, infaq dan sedekah. Nilai terendah diperoleh oleh BPRS yang tidak mempublikasikan besaran zakat yang dikeluarkan pada laporan keuangannya yaitu BPRS Artha Fisabilillah Kabupaten Cianjur, BPRS Mentari Kabupaten Garut, BPRS Gotong Royong Kabupaten Subang, BPRS Al Madinah Kota Tasikmalaya, BPRS Daarut Tauhiid Kota Cimahi, BPRS Al Barokah Kota Depok dan BPRS Artha Karimah Irsyadi Kota Bekasi.

Rasio yang ketiga dari tujuan yang ketiga yaitu investasi sektor riil (invesment ratios in real sector). Rasio ini tercermin dari total investasi BPRS pada sektor rill dibandingkan dengan total investasi yang dilakukan oleh BPRS. dari tabel di atas dapat diketahui BPRS di Provinsi Jawa Barat tidak ada yang melaporkan alokasi dana untuk investasi sektor riil pada laporan keuangannya. Hal ini dapat terjadi karena BPRS hanya dapat melakukan kegiatan penghimpunan dana dan penyaluran dana. Adiyudha \& Amanda (2019) menjelaskan bahwa BPRS menempatkan dananya pada bank syariah lain dalam bentuk titipan berdasarkan akad wadi'ah atau investasi berdasarkan akad mudharabah dan atau akad lain yang tidak bertentangan dengan prinsip syariah. 


\subsection{Sharia Maqashid Index (SMI) Bank Pembiayaan Rakyat Syariah}

Sebelum menghitung nilai SMI, perlu dilakukan penilaian indikator BPRS dengan menentukan peringkat kinerja maqashid syariah pada BPRS di Provinsi Jawa Barat. Hal ini dilakukan untuk mengetahui BPRS mana yang memiliki nilai Sharia Maqashid Index (SMI) tertinggi dan terendah. Proses ini dilakukan dengan menggunakan Indikator Kinerja (IK) setiap BPRS. Untuk mengetahui nilai IK maka perlu digunakan metode yang dinamakan simple weighting method (SAW) dengan cara pembobotan, agregat dan proses menentukan peringkat seperti yang dijelaskan pada bab sebelumnya. Berikut ini merupakan indikator kinerja (IK) setiap BPRS di Provinsi Jawa Barat berdasarkan tujuan-tujuan maqahid syariah adalah sebagai berikut:

\section{Tabel 7}

Indikator Kinerja Maqashid Syariah Tujuan Pertama (Tahdzib Al Fard) BPRS di Provinsi Jawa Barat Tahun 2016-2018

\begin{tabular}{|c|c|c|c|}
\hline \multirow{2}{*}{ Bank } & \multicolumn{2}{|c|}{ Indikator Kinerja Tujuan 1 (IK-T1) (30\%) } & \multirow{2}{*}{ Total } \\
\cline { 2 - 3 } & $\mathrm{IK}_{1.1}, \mathrm{IK}_{3.1}(50 \%)$ & $\mathrm{IK}_{2.1} \mathrm{IK}_{4.1}(50 \%)$ & 0,115030239 \\
\hline $\begin{array}{c}\text { BPRS Artha Madani (Kab. } \\
\text { Bekasi) }\end{array}$ & 0,080299854 & 0,034730385 & 0,115624088 \\
\hline $\begin{array}{c}\text { BPRS Amanah Ummah } \\
\text { (Kab. Bogor) }\end{array}$ & 0,088843926 & 0,026780162 & 0,075083325 \\
\hline $\begin{array}{c}\text { BPRS Artha Fisabilillah } \\
\text { (Kab. Cianjur) }\end{array}$ & 0,053141033 & 0,021942292 & 0,131013948 \\
\hline $\begin{array}{c}\text { BPRS Amanah Rabbaniah } \\
\text { (Kab. Bandung) }\end{array}$ & 0,095949434 & 0,035064515 & 0,141247524 \\
\hline BPRS Mentari (Kab. Garut) & 0,10364302 & 0,037604504 & 0,103984141 \\
\hline $\begin{array}{c}\text { BPRS Gotong Royong (Kab. } \\
\text { Subang) }\end{array}$ & 0,075932182 & 0,028051959 & 0,121138222 \\
\hline $\begin{array}{c}\text { BPRS Baiturridha Pusaka } \\
\text { (Kota Bandung) }\end{array}$ & 0,088369241 & 0,032768982 & 0,115866131 \\
\hline $\begin{array}{c}\text { BPRS Al Madinah (Kota } \\
\text { Tasikmalaya) }\end{array}$ & 0,100172603 & 0,029501339 & 0,124256316 \\
\hline $\begin{array}{c}\text { BPRS Daarut Tauhiid (Kota } \\
\text { Cimahi) }\end{array}$ & 0,071537479 & 0,044328652 & 0,141749575 \\
\hline $\begin{array}{c}\text { BPRS Al Barokah (Kota } \\
\text { Depok) }\end{array}$ & 0,084304841 & 0,039951475 & 0,05700948 \\
\hline $\begin{array}{c}\text { BPRS Artha Karimah Irsyadi } \\
\text { (Kota Bekasi) }\end{array}$ & 0,084740095 & & \\
\hline
\end{tabular}

Sumber: Hasil Pengolahan Data (2020)

Berdasarkan pengolahan data di atas dapat terlihat indikator kinerja yang pertama dari tujuan pertama (Tahzib al-fard) yaitu mendidik individu. BPRS yang menempati nilai tertinggi dari indikator kinerja hibah pendidikan dan pelatihan yaitu BPRS Mentari Kabupaten Garut yang menyalurkan dananya untuk donasi pendidikan masyarakat dan untuk pelatihan atau pengembangan skill bagi seluruh stakeholdernya jika dibandingkan dengan BPRS lainnya. Nilai terendah untuk pemberian dana pendidikan dan pelatihan yaitu BPRS Artha Fisabilillah Kabupaten Cianjur. 
Indikator kinerja kedua dan keempat yaitu pemberian alokasi dana untuk donasi riset dan pengembangan dan publikasi, BPRS Artha Karimah Irsyadi Kota Bekasi memiliki nilai tertinggi dibandingkan dengan BPRS yang lainnya. Nilai terendah dalam indikator kinerja kedua dan keempat ini yaitu BPRS Artha Fisabilillah Kabupaten Cianjur. Nilai akumulasi dari keempat indikator kinerja tersebut yang memiliki nilai tertinggi dalam mencapai tujuan pertama (Tahdzib Al-fard) yaitu BPRS Artha Karimah Irsyadi Kota Bekasi. Hal ini menunjukan bahwa BPRS Artha Karimah Irsyadi Kota Bekasi telah melaksanakan aspek maqashid syariah paling baik dalam melaksanakan tujuan pertama jika dibandingkan BPRS lainnya.

\section{Tabel 8}

Indikator Kinerja Maqashid Syariah Tujuan Kedua (Iqamah Al Adl) BPRS di Provinsi Jawa Barat Tahun 2016-2018

\begin{tabular}{|c|c|c|c|c|}
\hline \multirow{2}{*}{ Bank } & \multicolumn{3}{|c|}{ Indikator Kinerja Tujuan 2 (IK-T2) (41\%) } & \multirow{2}{*}{ Total } \\
\hline & $\mathrm{IK}_{1.2}(30 \%)$ & $\mathrm{IK}_{2.2}(32 \%)$ & $\mathrm{IK}_{3.2}(38 \%)$ & \\
\hline $\begin{array}{l}\text { BPRS Artha Madani } \\
\text { (Kab. Bekasi) }\end{array}$ & 0 & 0,014348134 & 0 & 0,014348134 \\
\hline $\begin{array}{l}\text { BPRS Amanah } \\
\text { Ummah (Kab. Bogor) }\end{array}$ & 0 & 0,006835804 & 0 & 0,006835804 \\
\hline $\begin{array}{ll}\text { BPRS } & \text { Artha } \\
\text { Fisabilillah } & \text { (Kab. } \\
\text { Cianjur) } & \\
\end{array}$ & 0 & 0 & 0 & 0 \\
\hline $\begin{array}{lr}\text { BPRS } & \text { Amanah } \\
\text { Rabbaniah } & \text { (Kab. } \\
\text { Bandung) } & \end{array}$ & 0 & 0,001914205 & 0 & 0,001914205 \\
\hline $\begin{array}{l}\text { BPRS Mentari (Kab. } \\
\text { Garut) }\end{array}$ & 0 & 0,006961951 & 0 & 0,006961951 \\
\hline $\begin{array}{l}\text { BPRS Gotong Royong } \\
\text { (Kab. Subang) }\end{array}$ & 0 & 0,028966645 & 0 & 0,028966645 \\
\hline $\begin{array}{l}\text { BPRS Baiturridha } \\
\text { Pusaka (Kota Bandung) }\end{array}$ & 0 & 0,001547283 & 0 & 0,001547283 \\
\hline $\begin{array}{l}\text { BPRS Al Madinah } \\
\text { (Kota Tasikmalaya) }\end{array}$ & 0 & 0,004931217 & 0 & 0,004931217 \\
\hline $\begin{array}{l}\text { BPRS Daarut Tauhiid } \\
\text { (Kota Cimahi) }\end{array}$ & 0 & 0,017440686 & 0 & 0,017440686 \\
\hline $\begin{array}{l}\text { BPRS Al Barokah } \\
\text { (Kota Depok) }\end{array}$ & 0 & 0,012436521 & 0 & 0,012436521 \\
\hline $\begin{array}{l}\text { BPRS Artha Karimah } \\
\text { Irsyadi (Kota Bekasi) }\end{array}$ & 0 & 0,008850155 & 0 & 0,008850155 \\
\hline
\end{tabular}

Sumber: Hasil Pengolahan Data (2020)

Berdasarkan pengolahan data di atas dapat terlihat perolehan nilai dari indikator kinerja untuk tujuan kedua yaitu menegakan keadilan (Iqamah Al-Adl). Indikator kinerja yang pertama yaitu pengembalian yang adil (Fair Returns), karena belum diterapkannya PER maka tidak ada BPRS yang melaporkannya, sehingga indikator kinerja yang pertama bernilai 0 . Indikator kinerja kedua yaitu fungsi distribusi 
(fungsional distribution) yaitu seberapa besar investasi yang diberikan dengan menggunakan skim bagi hasil dan yang memiliki nilai tertunggi yaitu BPRS Gotong Royong Kabupaten Subang dalam periode 2011-2016. Nilai terendah diperoleh oleh BPRS Baiturridha Pusaka Kota Bandung atas pemberian pembiayaan yang dilakukan dengan skim bagi hasil yang hanya mencapai 0,00155. Namun terdapat satu BPRS yang tidak melaporkan besaran dana investasi berdasarkan skim bagi hasil yaitu BPRS Artha Fisabilillah Kabupaten Cianjur.

Indikator kinerja ketiga yaitu produk bank non bunga (interest free product). Pada tabel di atas BPRS di Provinsi Jawa Barat tidak ada yang melaporkan alokasi dana untuk produk bank non bunga pada laporan keuangannya. Hal ini dapat menunjukan bahwa seluruh BPRS di Provinsi Jawa Barat pendapatannya bukan berasal dari hasil riba/bunga. Perolehan nilai indikator kinerja tetinggi yaitu BPRS Gotong Royong Kabupaten Subang untuk pelaksanaan tujuan yang kedua. Hal ini menunjukan bahwa BPRS Gotong Royong Kabupaten Subang merupakan BPRS yang paling dalam melaksanakan tujuan kedua yaitu menciptakan keadilan.

Tabel 9

Indikator Kinerja Maqashid Syariah Tujuan Ketiga (Jalb Al Maslahah) BPRS di Provinsi Jawa Barat Tahun 2016-2018

\begin{tabular}{|l|c|c|c|c|}
\hline \multicolumn{1}{|c|}{ Bank } & \multicolumn{2}{|c|}{ Indikator Kinerja Tujuan 3 (IK-T3) (29\%) } & \multirow{2}{*}{ Total } \\
\cline { 2 - 4 } & $\mathrm{IK}_{1.3}(33 \%)$ & $\mathrm{IK}_{2.3}(30 \%)$ & $\mathrm{IK}_{3.3}(37 \%)$ & 0 \\
\hline $\begin{array}{l}\text { BPRS Artha Madani (Kab. } \\
\text { Bekasi) }\end{array}$ & 0,000493892 & $\begin{array}{c}0,0089342 \\
18\end{array}$ & 0 & 0,00942811 \\
\hline $\begin{array}{l}\text { BPRS Amanah Ummah (Kab. } \\
\text { Bogor) }\end{array}$ & 0,001541561 & $\begin{array}{c}0,0085152 \\
02\end{array}$ & 0 & 0,010056764 \\
\hline $\begin{array}{l}\text { BPRS Artha Fisabilillah (Kab. } \\
\text { Cianjur) }\end{array}$ & $-0,006665878$ & 0 & 0 & 0,006665878 \\
\hline $\begin{array}{l}\text { BPRS Amanah Rabbaniah } \\
\text { (Kab. Bandung) }\end{array}$ & 0,001916173 & $\begin{array}{c}0,0009411 \\
87\end{array}$ & 0 & 0,00285736 \\
\hline BPRS Mentari (Kab. Garut) & 0,001401386 & 0 & 0 & 0,001401386 \\
\hline $\begin{array}{l}\text { BPRS Gotong Royong (Kab. } \\
\text { Subang) }\end{array}$ & $-0,003439857$ & 0 & 0 & 0,003439857 \\
\hline $\begin{array}{l}\text { BPRS Baiturridha Pusaka (Kota } \\
\text { Bandung) }\end{array}$ & 0,002679627 & 0,0193335 & 0 & 0,02201313 \\
\hline $\begin{array}{l}\text { BPRS Al Madinah (Kota } \\
\text { Tasikmalaya) }\end{array}$ & 0,00068277 & 0 & 0 & 0,00068277 \\
\hline $\begin{array}{l}\text { BPRS Daarut Tauhiid (Kota } \\
\text { Cimahi) }\end{array}$ & $-0,000684829$ & 0 & 0 & 0,000684829 \\
\hline BPRS Al Barokah (Kota Depok) & 0,00217316 & 0 & 0 & 0,00217316 \\
\hline $\begin{array}{l}\text { BPRS Artha Karimah Irsyadi } \\
\text { Kota Bekasi) }\end{array}$ & 0,000416861 & 0 & 0 & 0,000416861 \\
\hline
\end{tabular}

Sumber : Hasil Pengolahan Data (2020)

Berdasarkan pengolahan data di atas dapat terlihat nilai dari indikator kinerja maqashid syariah untuk tujuan ketiga yaitu menciptakan kesejahteraan (Jalb Al- 
Maslahah). Indikator kinerja yang pertama yaitu rasio laba (profit ratio) yaitu BPRS yang memiliki profitabilitas tinggi pada periode 2016-2018 yaitu BPRS Baiturridha Pusaka Kota Bandung yang memperoleh nilai sebesar 0,00268. Nilai terendah pada indikator kinerja pertama yaitu BPRS Daarut Tauhiid Kota Cimahi yang memperoleh nilai sebesar $-0,000685$.

Perolehan nilai tertinggi atas pendapatan personal (personal income) yang diukur dengan penyaluran dana zakat pada periode 2016-2018 diduduki oleh BPRS yang sama yaitu BPRS Baiturridha Pusaka Kota Bandung. Nilai terendah dalam penyaluran zakat diperoleh oleh BPRS yang belum melaporkan dana zakat pada laporan keuangannya yaitu BPRS Artha Fisabilillah Kabupaten Cianjur, BPRS Mentari Kabupaten Garut, BPRS Gotong Royong Kabupaten Subang, BPRS Al Madinah Kota Tasikmalaya, BPRS Daarut Tauhiid Kota Cimahi, BPRS Al Barokah Kota Depok dan BPRS Artha Karimah Irsyadi Kota Bekasi.

Indikator kinerja ketiga yaitu investasi sektor riil (invesment ratios in real sector) atau penyaluran pembiayaan pada sektor rill. Pada tabel di atas dapat diketahui BPRS di Provinsi Jawa Barat tidak ada yang melaporkan alokasi dana untuk investasi sektor riil pada laporan keuangannya. Hal ini dapat terjadi karena BPRS hanya dapat melakukan kegiatan penghimpunan dana dan penyaluran dana saja berbeda dengan Bank Umum Syariah (BUS) yang lebih bersifat umum. Perolehan nilai indikator kinerja tetinggi yaitu BPRS Baiturridha Pusaka Kota Bandung untuk pelaksanaan tujuan yang ketiga. Hal ini menunjukan bahwa BPRS Baiturridha Pusaka Kota Bandung merupakan BPRS yang paling baik dalam melaksanakan tujuan ketiga yaitu menciptakan kesejahteraan.

Tahapan selanjutnya setelah mengetahui nilai dari setiap indikator kinerja pada tiga tujuan di atas, maka untuk mengetahui nilai Sharia Maqashid Index (SMI) yaitu dengan cara menjumlahkan total dari setiap indikator kinerja tiga tujuan maqashid syariah. Berikut ini merupakan tabel Index Maqashid Syariah (IMS) BPRS pada periode 2016-2018:

Tabel 10

Index Maqashid Syariah (IMS) Bank Pembiayaan Rakyat Syariah

\begin{tabular}{|l|l|l|l|l|l|}
\hline Bank & IK (T1) & IK (T2) & IK (T3) & IMS & Rangking \\
\hline $\begin{array}{l}\text { BPRS Artha Madani (Kab. } \\
\text { Bekasi) }\end{array}$ & 0,115030239 & 0,014348134 & 0,00942811 & $\begin{array}{l}0,1388 \\
06483\end{array}$ & 5 \\
\hline $\begin{array}{l}\text { BPRS Amanah Ummah } \\
\text { (Kab. Bogor) }\end{array}$ & 0,115624088 & 0,006835804 & $\begin{array}{l}0,01005676 \\
4\end{array}$ & $\begin{array}{l}0,1325 \\
16656\end{array}$ & 9 \\
\hline $\begin{array}{l}\text { BPRS Artha Fisabilillah } \\
\text { (Kab. Cianjur) }\end{array}$ & 0,075083325 & 0 & $\begin{array}{l}-0,00666587 \\
8\end{array}$ & $\begin{array}{l}0,0684 \\
17446\end{array}$ & 11 \\
\hline $\begin{array}{l}\text { BPRS Amanah Rabbaniah } \\
\text { (Kab. Bandung) }\end{array}$ & 0,131013948 & 0,001914205 & 0,00285736 & $\begin{array}{l}0,1357 \\
85513\end{array}$ & 6 \\
\hline BPRS Mentari (Kab. Garut) & 0,141247524 & 0,006961951 & $\begin{array}{l}0,00140138 \\
6\end{array}$ & $\begin{array}{l}0,1496 \\
1086\end{array}$ & 2 \\
\hline $\begin{array}{l}\text { BPRS Gotong Royong (Kab. } \\
\text { Subang) }\end{array}$ & 0,103984141 & 0,028966645 & $\begin{array}{l}- \\
0,00343985 \\
7\end{array}$ & $\begin{array}{l}0,1295 \\
1093\end{array}$ & 10 \\
\hline
\end{tabular}




\begin{tabular}{|l|l|l|l|l|l|}
\hline Bank & IK (T1) & IK (T2) & IK (T3) & IMS & Rangking \\
\hline $\begin{array}{l}\text { BPRS Baiturridha Pusaka } \\
\text { (Kota Bandung) }\end{array}$ & 0,121138222 & 0,001547283 & 0,02201313 & $\begin{array}{l}0,1446 \\
98635\end{array}$ & 3 \\
\hline $\begin{array}{l}\text { BPRS Al Madinah (Kota } \\
\text { Tasikmalaya) }\end{array}$ & 0,129673943 & 0,004931217 & 0,00068277 & $\begin{array}{l}0,1352 \\
87929\end{array}$ & 7 \\
\hline $\begin{array}{l}\text { BPRS Daarut Tauhiid (Kota } \\
\text { Cimahi) }\end{array}$ & 0,115866131 & 0,017440686 & $\begin{array}{l}-0,00068482 \\
9\end{array}$ & $\begin{array}{l}0,1326 \\
21988\end{array}$ & 8 \\
\hline $\begin{array}{l}\text { BPRS Al Barokah (Kota } \\
\text { Depok) }\end{array}$ & 0,124256316 & 0,012436521 & 0,00217316 & $\begin{array}{l}0,1388 \\
65997\end{array}$ & 4 \\
\hline $\begin{array}{l}\text { BPRS Artha Karimah Irsyadi } \\
\text { (Kota Bekasi) }\end{array}$ & 0,141749575 & 0,008850155 & $\begin{array}{l}0,00041686 \\
1\end{array}$ & $\begin{array}{l}0,1510 \\
1659\end{array}$ & 1 \\
\hline
\end{tabular}

Sumber: Hasil Pengolahan Data (2020)

Berdasarkan tabel 10 di atas dapat terlihat yang paling baik dalam pelaksanaan tujuan pertama (Tahzib al-Fard) yaitu BPRS Artha Karimah Irsyadi Kota Bekasi hal ini dikarenakan BPRS tersebut didukung oleh nilai biaya penelitian dan publikasi yang paling tinggi. Pelaksanaan pada tujuan kedua (Iqamah al-Adl) yang memiliki nilai terbaik yaitu BPRS Gotong Royong Kabupaten Subang, hal ini dikarenakan BPRS tersebut didukung oleh aspek fungsi distribusi yang paling tinggi dilihat rasio pembiayaan dengan skim bagi hasil yaitu mudharabah dan musyarakah dibandingkan dengan pembiayaan dengan skim lain. Pelaksanaan pada tujuan ketiga (Jalb alMaslahah) yang memiliki nilai paling baik yaitu BPRS Baiturridha Pusaka Kota Bandung hal ini dikarenakan BPRS tersebut memiliki nilai paling tinggi dalam rasio laba.

Secara umum yang memiliki nilai SMI tertinggi pertama untuk semua tujuan pada periode 2016-2018 yaitu BPRS Artha Karimah Irsyadi Kota Bekasi, hal ini dikarenakan BPRS Artha Karimah Irsyadi Kota Bekasi telah didukung oleh perolehan nilai tertinggi dalam pencapaian indikator kinerja pertama, sehingga perolehan nilai SMI menjadi tinggi. Kemudian yang memiliki nilai SMI tertinggi kedua untuk semua tujuan pada periode 2016-2018 yaitu BPRS Mentari Kabupaten Garut dan yang memiliki nilai SMI tertinggi ketiga untuk semua tujuan pada periode 2016-2018 yaitu BPRS Baiturridha Pusaka Kota Bandung. Hal ini membuktikan bahwa jika SMI yang diperoleh semakin tinggi maka kinerja BPRS tersebut memiliki kinerja semakin baik dalam melaksanakan tujuan maqashid syariah yang menjadi tujuan utama dalam pencapaian perbankan syariah, sehingga tidak hanya keuntungan yang tinggi yang diperoleh tetapi juga bagaimana kemaslahatan/ketercapaian tujuan syariah terimplementasikan dalam kegiatan operasional BPRS tersebut.

\section{PENUTUP}

\subsection{Kesimpulan}

Berdasarkan hasil penelitian dan pembahasan yang telah diuraikan pada bab sebelumnya maka dapat ditarik kesimpulan bahwa hasil pengukuran kinerja BPRS berdasarkan maqashid syariah yang dilakukan pada tahun 2016-2018, yang menduduki ranking pertama yaitu BPRS Artha Karimah Irsyadi Kota Bekasi. Hal ini dikarenakan 
BPRS Artha Karimah Irsyadi Kota Bekasi telah didukung oleh perolehan nilai tertinggi dalam pencapaian indikator kinerja tujuan pertama (Tahdzib Al fard) pada rasio penelitian dan publikasi, sehingga perolehan nilai SMI menjadi tinggi. Kemudian yang memiliki nilai SMI tertinggi kedua untuk semua tujuan pada periode 2016-2018 yaitu BPRS Mentari Kabupaten Garut karena didukung oleh pencapaian tertinggi dalam indikator kinerja tujuan pertama (Tahdzib Al fard) pada rasio pemberian hibah pendidikan dan pelatihan. Selanjutnya BPRS yang menduduki rangking ketiga dalam perolehan nilai SMI periode 2016-2018 adalah BPRS Baiturridha Pusaka Kota Bandung. Hal ini dikarenakan BPRS Baiturridha Pusaka Kota Bandung didukung oleh pencapaian nilai tertinggi pada indikator kinerja tujuan ketiga (Jalb Al Maslahah) yaitu pada rasio laba dan rasio pendapatan personal.

Implikasi yang dapat diterapkan dalam penelitian ini adalah semakin tinggi nilai Sharia Maqashid Index (SMI) maka tujuan maqashid syariah pada BPRS tersebut telah dapat terimplementasikan dengan baik, dengan kata lain BPRS tersebut tidak hanya memfokuskan pada pencapaian keuntungan materil semata, namun juga memperhatikan ketercapaian tujuan syariah diantaranya aspek mendidik individu, mewujudkan keadilan dan memperhatikan kepentingan masyarakat. Sebaliknya jika nilai SMI semakin rendah maka tujuan maqashid syariah pada BPRS tersebut dapat dikatakan belum maksimal, sehingga sangat perlu suatu Lembaga Keuangan Islam seperti BPRS memperhatikan ketercapaian tujuan syariah nya selain untuk mendapatkan ridho Allah swt, memperhatikan ketercapaian tujuan syariah juga dapat membantu BPRS bersaing dengan Lembaga Keuangan konvensional lainnya dan juga untuk meyakinkan masyarakat bahwa kinerja yang dijalankan BPRS telah sesuai dengan konsep syariah, maka hal ini akan menjawab kekhawatiran masyarakat dan menjelaskan kepada masyarakat yang masih berfikir bahwa bank syariah sama dengan bank konvensional.

\subsection{Saran}

Adapun rekomendasi penulis berdasarkan penelitian yang telah dilakukan adalah sebagai berikut:

1. Dewan Pengawas Syariah (DPS) di Indonesia seharusnya telah mulai menerapkan model evaluasi kinerja yang sesuai dengan prinsip syariah bagi Lembaga Keuangan Syariah. DPS juga harus mulai membuat kebijakan tentang laporan keuangan dengan aspek syariah yang komprehensif dan menggambarkan bahwa bank syariah telah menjalankan tujuan dan nilai syariah dalam aktivitas perbankannya. Model evaluasi kinerja Sharia Maqashid Index (SMI) ini juga akan lebih akurat apabila memiliki patokan kriteria kinerja maqashid syariah sehingga akan dapat mempertegas dari hasil penelitian sebuah Lembaga Keuangan Syariah tersebut telah memenuhi kriteria maqashid syariah atau tidak.

2. Bank Pembiayaan Rakyat Syariah (BPRS) perlu memperhatikan beberapa rasio kinerja maqashid syariah yang menjadi ukuran dalam penentuan kinerja BPRS. Hasil penelitian ini dapat menjadi evaluasi kebijakan manajemen dalam 
menentukan arah kerja BPRS kedepannya seperti pada BPRS Artha Fisabilillah Kabupaten Cianjur yang memiliki nilai SMI terendah terutama pada Indikator Kinerja Tujian kedua dan ketiga, sehingga dapat meningkatkan kinerja dan mengevaluasinya untuk tahun berikutnya.

3. Untuk peneliti selanjutnya hendaknya menambah variabel rasio keuangan lainnya untuk bahan perbandingan antara kinerja keuangan dengan kinerja maqashid syariah untuk mengukur kinerja BPRS. Selain itu diharapkan penelitian selanjutnya dapat mengusulkan pengukuran kinerja BPRS menggunakan Sharia Maqashid Index (SMI) yang berbeda dengan pengukuran kinerja pada BUS berdasarkan Sharia Maqashid Index (SMI). Dikarenakan pengukuran SMI yang digunakan untuk BPRS berbeda dengan pengukuran SMI yang digunakan untuk BUS, sehingga ada beberapa rasio yang terpaksa tidak bisa diperhitungkan seperti rasio Profit Equalization Reserve (PER) dan rasio investasi pada sector riil.

\section{DAFTAR PUSTAKA}

Adiyudha, R., \& Amanda, G. (2019, November 28). Perbedaan Bank Umum Syariah dan Bank Pembiayaan Syariah. Retrieved from republika.co.id: https://www.google.com/amp/s/m.republika.co.id/amp/q1mot5423?espv=1

Afrinaldi. (2013). Analisis Kinerja Perbankan Syariah indonesia ditinjau dari Maqashid Syariah: Pendekatan Sharia Maqashid Index (SMI) dan Profitabilitas Bank Syariah. Jakarta: Islamic Economic \& Finance (IEF) Universitas Trisakti.

Amirullah. (2015). Populasi dan Sampel. Malang: Bayumedia Publishing Malang.

Antonio, M. S., Sanrego, Y. D., \& Taufiq, M. (2012). An Analysis of Islamic Banking Performance: Maqashid Index Implementation in Indonesia and Jordania. Journal of Islamic Finance Vol.1 No.1 IIUM Institute of Islamic Banking and Finance ISSN 2289-2117.

Batin, M. H. (2017). Kinerja Keuangan Bank Pembiayaan Rakyat Syariah Melalui Pendekatan Maqashid Syariah Index (MSI) dan Profitabilitas. Nurani, Vol. 17, No. 1.

Ferdinand, A. (2014). Metode Penelitian Manajemen (Pedoman Penelitian untuk Penulisan Skripsi, Tesis, dan Disertasi Ilmu Manajemen). Semarang: Badan Penerbit Universitas Diponegoro.

Hasan, N. F. (2017). Analisis Kinerja Perbankan Syariah (Implementasi Maqashid alSyariah Index di PT BPRS Jabal Nur). 'Anil Islam Vol. 10 No. 1.

Jaya, M. K., Mulyadi, D., \& Sulaeman, E. (2012). Pengaruh Kecerdasan Emosional terhadap Kinerja Karyawan pada Kantor Kementerian Agama Kabupaten Karawang. Jurnal Manajemen Vol. 10, No. 1, 1039.

Mahsun, F. d. (2011). Akuntansi Sektor Publik. Yogyakarta: Edisi Ketiga BPFE.

Mohammed, M. O., \& Razak, D. A. (2008). The Performance Measures of Islamic Banking Based on the Maqasid Framework. IIUM International Accounting Conference (INTAC IV). 
324 Aneu Cakhyaneu, Fani Puspitasari, Heraeni Tanuatmodjo dan Firmansyah

Nurfadhilah, N. (2018). Analisis Pengukuran Kinerja Perbankan Syariah berdasarkan Sharia Maqashid Index (SMI) dan Profitabilitas pada Bank Umum Syariah (BUS). Universitas Pendidikan Indonesia, repository.upi.edu, 65.

Ramadhan, B. M., \& Ryandono, M. N. (2015). Etos Kerja Islami pada Kinerja Bisnis Pedagang Muslim Pasar Besar Kota Madiun. JESTT Vol. 2 No. 4, 280-281.

Rosanti, R. A. (2019). Telaah Kinerja Keuangan Perbankan Syariah Dengan Pendekatan Sharia Maqashid Index Di Indonesia. The 5th SNCP 2019 - ISBN : 978-602-6988-71-3.

Safwan, Nadirsyah, \& Abdullah, S. (2014). Pengaruh Kompetensi dan Motivasi terhadap Kinerja Pengelolaan Keuangan Daerah pada Pemerintah Daerah Kabupaten PIDIE JAYA. Jurnal Akuntansi, Pascasarjana Universitas Syiah Kuala, Vol. 3, No. 1, ISSN 2302-0164, 133.

Shidiq, G. (2009). Teori Maqashid Al-Syari'ah Dalam Hukum Islam. SULTAN AGUNG Vol. XLIV No. 118.

Suryana. (2010). Metodologi Penelitian Model Praktis Penelitian Kuantitatif dan Kualitatif. Bandung: Universitas Pendidikan Indonesia.

Triandini, H. (2013). Pengaruh Layanan Jemput Bola Produk Funding Terhadap DPK dan Jumlah Nasabah: Studi pada BPRS Artha Karimah Irsyadi. Jurnal Etikonomi Vol. 12 No. 2, 132.

Wahidmurni. (2017). Pemaparan Metode Penelitian Kuantitatif. UIN Maulana Malik Ibrahim Malang, 1. 